\title{
Pengaruh Peran Ganda Terhadap Kinerja Tenaga Medis Wanita Melalui Stres Kerja
}

Woman Medical

Personnel

Performance

\author{
Maria Laurensia Yusifina Dengi Dando, Rolland E. Fanggidae, \\ Apriana H. J. Fanggidae \\ Program Studi Manajemen Universitas Nusa Cendana Kupang, Indonesia \\ EMail: uchy.dando98@gmail.com
}

\section{ABSTRACT}

This study aims to determine whether the dual role affects the performance of female medical personnel through work stress at the Baun Community Health Center, Kupang Regency. The method used in this research is an associative quantitative approach. This research was conducted at the Baun Community Health Center, Kupang Regency with a sample size of 38 people using total sampling, and to collect data in the field using a questionnaire. The analysis technique used in this research is multiple linear regression analysis and intervening. The results of the study found that partially multiple roles have an effect on the work stress of female medical personnel, while job stress has no effect on the performance of female medical personnel. Meanwhile, simultaneously multiple roles and job stress have an effect on the performance of female medical personnel and multiple roles can affect performance with job stress as an intervening variable.

Keywords: multiple roles, job stress, performance, intervening , puskesmas baun kabupaten kupang

\begin{abstract}
ABSTRAK
Tujuan Penelitian ini adalah untuk mengetahui apakah Peran Ganda dan Stres Kerja berpengaruh secara parsial terhadap Kinerja tenaga medis wanita, apakah Peran Ganda dan Stres Kerja secara simultan berpengaruh terhadap Kinerja tenaga medis wanita dan apakah Peran Ganda Berpengaruh terhadap Kinerja tenaga medis wanita melalui Stres Kerja di Puskesmas Baun Kabupaten Kupang. Metode yang digunakan dalam adalah pendekatan kuantitatif asosiatif. Penelitian ini di laksanakan pada Puskesmas Baun Kabupaten Kupang dengan jumlah sampel 38 orang dengan mengunakan total sampling, dan untuk mengumpulkan data di lapangan menggunakan kuesioner. Teknik analisis yang digunakan dalam penelitian ini adalah analisis regresis linier berganda dan uji sobel. Hasil Penelitian menemukan bahwa secara parsial peran ganda berpengaruh terhadap stres kerja tenaga medis wanita, sedangkan stres kerja tidak berpengaruh terhadap kinerja tenaga medis wanita. Sementara itu secara simultan peran ganda dan stress kerja berpengaruh terhadap kinerja tenaga medis wanita dan Stres Kerja tidak dapat memediasi pengaruh Peran Ganda terhadap Kinerja tenaga medis melalui Stres Kerja sebagai variable intervening.
\end{abstract}

Kata Kunci : Peran Ganda, Stress Kerja, Kinerja, Intervening, Puskesmas Baun Kabupaten Kupang

\section{PENDAHULUAN}

Manajemen sumber daya manusia merupakan suatu perencanaan, pengorganisasian, pengkoordinasian, pelaksanaan, dan pengawasan terhadap pengadaan, pengembangan, pemberian balas jasa, pengintegrasian, dan pemisahan tenaga kerja dalam rangka mencapai tujuan organisasi (Mangkunegara, 2013). Tujuan organisai dapat tercapai apabila memiliki
Submitted: MARET 2021

Accepted: APRIL 2021

\section{JIMKES}


Women Medical

Personnel

Performance

178 sumber daya yang berkualitas. Sumber daya manusia yang memiliki kualitas yang baik maka akan menunjang laju kehidupan organisasi dapat berjalan dengan baik (Arikunto, 2011). Hal ini berarti bahwa suatu organisasi dapat berhasil apabila dapat mencapai tujuan yang ada dalam organisasi dan didukung dengan sumber daya manusia. Organisasi adalah suatu sistem perserikatan formal, berstruktur, dan terkoordinasi dari sekelompok orang yang bekerja sama dalam mencapai tujuan tertentu (Hasibuan, 2011). Perilaku organisasi akan selalu berhubungan dengan pekerjaan dan situasi lingkungan maka akan banyak perilaku yang saling berkaitan pula seperti tugas kerja, kehadiran, perpindahan pekerjaan, produktivitas, penampilan manusia, manajemen dan kinerja karyawan.

Widodo (2006) mengemukakan kinerja adalah melakukan suatu kegiatan dan menyempurnakan sesuai dengan tanggung jawabnya dengan hasil seperti yang diharapkan. Namun, dalam menyelesaikan tugas dan tanggung jawabnya didalam pekerjaan terkadang terdapat gangguan atau masalah-masalah dalam diri seorang wanita, misalnya wanita merasa bersalah telah meninggalkan keluarganya untuk bekerja, tertekan karena terbatasnya waktu dan beban pekerjaan terlalu banyak serta situasi kerja yang kurang menyenangkan. Hal ini mengenai gangguan atau masalah-masalah tersebut dapat mengakibatkan pada kinerja dari pekerja semakin berkurang, oleh karena itu pihak perusahaan perlu memperhatikannya sehingga kinerja dapat meningkat. Iswari dan Radhanawati (2018), mengungkapkan bahwa kinerja dari karyawan dapat di pengaruhi oleh stres kerja. Stres kerja yang tinggi dari seorang karyawan akan dapat mengganggu kinerja yang dimilikinya. Sehingga perlu diperhatikan dampak dari yang mempengaruhi stres kerja untuk mencegahnya dalam meningkatkan kinerja.

Robbins (2004), menyatakan bahwa stres kerja merupakan suatu kondisi yang menyebabkan terjadinya ketegangan sehingga mempengaruhi emosi, proses berpikir, dan kondisi seseorang ditempat kerja. Stres kerja yang tinggi dan tidak dapat dikendalikan oleh karyawan dapat mengancam kemampuan karyawan dalam bekerja yang akhirnya menganggu pelaksanaan tugas-tugasnya dan kemudian dapat menurunkan kinerjanya (Handoko, 2008). Selain Stres kerja yang dapat mempengaruhi kinerja juga terdapat faktor lain yang mempengaruhi kinerja yaitu peran ganda (Imelda dan Asthenu, 2009).

Cinamon dan Rich (2002) menunjukkan wanita atau ibu yang bekerja ternyata lebih sering mengalami work family conflict dan lebih menekankan pentingnya family work conflict, ketika keluarga sebagai domain yang paling penting bagi kebanyakan wanita mempengaruhi pekerjaan mereka dan dapat menjadi gangguan bagi mereka.

Puskesmas (Pusat Kesehatan Masyarakat) Baun merupakan salah satu puskesmas perawatan di Kabupaten Kupang yang melayani pasien rawat jalan dan rawat inap. Tenaga medis merupakan komponen penting dalam pelayanan kesehatan di puskesmas. Selama 24 jam tenaga medis harus siap melayani kebutuhan pasien yang mengharuskan bekerja dalam shift. Permasalahan yang dihadapi yaitu, proses kerja yang membosankan dan sikap pasien yang emosional serta keterbatasan SDM dan peran sebagai wanita bekerja untuk memenuhi kebutuhan keluarga dan sebagai ibu rumah tangga yang sama- sama membutuhkan waktu, tenaga, dan perhatian (Almasitoh, 2011). Seorang tenaga medis harus melakukan dinas pagi, siang ataupun malam sehingga terjadi kurangnya keterlibatan sebagai seorang istri dan juga sebagai orang tua karena waktu bersama keluarga dikorbankan untuk pekerjaan sehingga konsentrasi akan terbagi antara pekerjaan di puskemas dan keluarga dirumah mengakibatkan tenaga medis khususnya wanita tidak bisa memenuhi tanggung jawab sebagai ibu rumah tangga dan sebagai orang tua.

Peran ganda yang berkepanjangan akan memicu timbulnya stres, yang pada akhirnya akan mengganggu kinerja baik kinerja sebagai tenaga medis wanita maupun kinerja sebagai ibu rumah tangga. Untuk itu disinilah pentingnya kesadaran diri bagi seorang wanita untuk memahami konsekuensi atas pilihan untuk tetap bekerja. Tenaga medis wanita harus dituntut untuk mengurus keperluan keluarganya termasuk suami dan anaknya dan disisi lain mereka 
harus bekerja untuk dapat menyelesaikan tugasnya sebagai seorang tenaga medis wanita dengan kondisi pekerjaan yang mengharuskan mereka bekerja lebih dari kemampuannya karna perkembangan karir.

Luthans (2005) menyatakan bahwa stres adalah suatu tanggapan untuk menyesuaikan diri, yang dipengaruhi oleh perbedaan individual atau proses psikologis yakni suatu konsekuensi dari setiap tindakan ekstern (lingkungan), situasi atau peristiwa yang terlalu banyak mengadakan tuntutan psikologis dan fisik terhadap seseorang. Stres berarti suatu tuntutan hal-hal yang sangat berbeda atau secara sederhana diartikan sebagai sesuatu yang melibatkan interaksi antara individu dengan lingkungan.

Robbins (2005) mendefinisikan stres kerja sebagai kondisi yang dinamis dimana seseorang dikonfrontasikan dengan kesempatan, hambatan, atau tuntutan yang berhubungan dengan apa yang diinginkannya dan untuk itu keberhasilannya ternyata tidak pasti. Triaryati (2003) dalam penelitiannya, karyawan wanita telah terbukti menderita depresi dan mengalami stres lebih cepat dibandingkan pria, merupakan korban terbesar dalam konflik peran ganda.

Stres kerja pada tingkat yang lebih berat akan menempatkan tuntutan yang tidak dapat dicapai atau kendala keseseorang, yang mengakibatkan kinerja menurun (Robbins, 2006). Tingkat stres yang mampu dikendalikan membuat tenaga medis melakukan pekerjaannya dengan lebih baik, karena membuat mereka mampu meningkatkan intensitas kerja, kewaspadaan, dan kemampuan berkreasi, tetapi tingkat stres kerja yang berlebihan membuat kinerja mereka akan mengalami penurunan (Robins, 2006).

Perempuan mulai masuk ke ruang publik untuk berbagai macam alasan, entah sebagai keinginan dari dalam diri sendiri ataupun sebuah keharusann yang membuatnya meninggalkan ruang domestiknya disebut sebagai kemajuan perempuan. Apalagi ditambah dengan perubahan sosial budaya yang terjadi, disinilah dimulai suatu pemisahan yang tajam antara peran perempuan saat berada diruang domestik untuk menjadi ibu rumah tangga dan saat berada diruang publik untuk bekerja (Endah Susilantini,2006). Peran ganda adalah dua peran atau lebih yang dijalankan dalam waktu yang bersamaan. Dalam hal ini peran yang dimaksud adalah peran seorang perempuan sebagai istri bagi suaminya, ibu bagi anakanaknya, dan peran sebagai perempuan yang memiliki karir diluar rumah. Peran ganda ini dijalani bersamaan dengan peran kaum perempuan sebagai istri dan ibu dalam keluarga, seperti menjadi mitra suami dalam membina rumah tangga, menyediakan kebutuhan rumah tangga, serta mengasuh dan mendidik anak-anak. (Denrich Suryadi, 2004). Konflik peran ganda adalah bentuk dari konflik antar peran yang mana tekanan peran dari pekerjaan dan keluarga bertentangan, artinya terdapat dua peran sekaligus yang harus dijalankan oleh wanita tersebut, yaitu sebagai istri, ibu, dan sebagai wanita yang sedang bekerja (Rahmadita, 2013). Triarty (2003), menyatakan bahwa konflik pekerjaan keluarga pada karyawan yang sudah menikah dan mempunyai anak dapat di definisikan sebagai bentuk konflik peran dimana tuntutan dari peran pekerjaan kurang dapat dipenuhi karena pada saat yang sama seseorang berusaha memenuhi tuntutan peran yang lain.

Gorda (2006), menyatakan kinerja adalah hasil kerja yang disumbangkan seorang karyawan yang berkaitan dengan tugas dan tanggung jawabnya kepada organisasi (perusahaan) yang didasarkan atas kecerdasan spiritual, intelegensia, emosional dan kecerdasan mengubah kendala menjadi peluang serta keterampilan fisik yang diarahkan kepada pemanfaatan sumberdaya yang disediakan oleh organisasi/perusahaan. Sejalan dengan pendapat Mangkunegara (2012) bahwa "kinerja karyawan adalah hasil kerja secara kualitas dan kuantitas yang dicapai oleh seorang karyawan dalam melaksanakan tugasnya sesuai dengan tanggung jawab yang diberikan kepadanya". Dari definisi kinerja tersebut dapat dilihat bahwa kinerja seorang karyawan berkaitan dengan tugas dan tanggung jawabnya dalam mencapai hasil kerja baik dari segi kualitas maupun kuantitas yang didasarkan pada kecerdasan spiritual, intelegensia dan emosional. 
Women Medical

Personnel

Performance
Kemudian Moeheriono (2012), menyatakan bahwa kinerja atau performance merupakan gambaran mengenai tingkat pencapaian pelaksanaan suatu program kegiatan atau kebijakan dalam mewujudkan sasaran, tujuan visi dan misi organisasi yang dituangkan melalui perencanaan strategis suatu organisasi. Sedangkan menurut Wibowo (2014), kinerja adalah tentang melakukan pekerjaan dan hasil yang dicapai dari pekerjaan tersebut. Kinerja adalah tentang apa yang dikerjakan dan bagaimana cara mengerjakannya.

\section{Kerangka Berpikir}

Cinamon dan Rich (2002) menunjukkan wanita atau ibu yang bekerja ternyata lebih sering mengalami work family conflict dan lebih menekankan pentingnya family work conflict, ketika keluarga sebagai domain yang paling penting bagi kebanyakan wanita mempengaruhi pekerjaan mereka dan dapat menjadi gangguan bagi mereka. tenaga medis wanita terkadang mengalami permasalahan dalam keluarga yaitu, tidak mendapat dukungan dan adanya keluhan akibat pekerjaan yang mereka lakukan serta tuntutan urusan keluarga yang membatasi jam kerja di Puskesmas mengharuskan mereka untuk bisa menjalankan tugas dan tanggung jawabnya dalam mengatur waktu, tenaga dan fikirannya agar tetap mampu memberikan kualitas dalam mengurus rumah tangga, namun disisi lain, sebagai seorang wanita karir tenaga medis wanita dituntut pula untuk bekerja sesuai dengan beban kerja dengan menunjukkan performan kerja yang baik sehingga terkadang dapat mengganggu konsentrasi didalam bekerja. Kondisi tersebut memicuh terjadinya konflik peran ganda yang jika tidak dapat ditangani secara tepat dan bijaksana, maka dapat berakibat langsung pada kinerja tenaga medis wanita.

Selain peran ganda, Stres kerja juga ikut memengaruhi kinerja karyawan. Stres kerja sebagai suatu bentuk tanggapan seseorang, baik fisik maupun mental terhadap suatu perubahan dilingkungannya yang dirasakan mengganggu dan mengakibatkan dirinya terancam (Anoraga, 2011). Stress kerja bukanlah suatu hal yang selalu berakibat buruk bagi para tenaga medis wanita \& kinerjanya, melainkan stres kerja juga dapat memberikan motivasi bagi tenaga medis wanita untuk memupuk rasa semangat dalam menjalankan setiap pekerjaannya sehingga mencapai suatu prestasi kerja yang baik. Pengelola stres yang dilakukan secara berkesinambungan maka tidak akan menghambat kinerja setiap tenaga medis wanita.

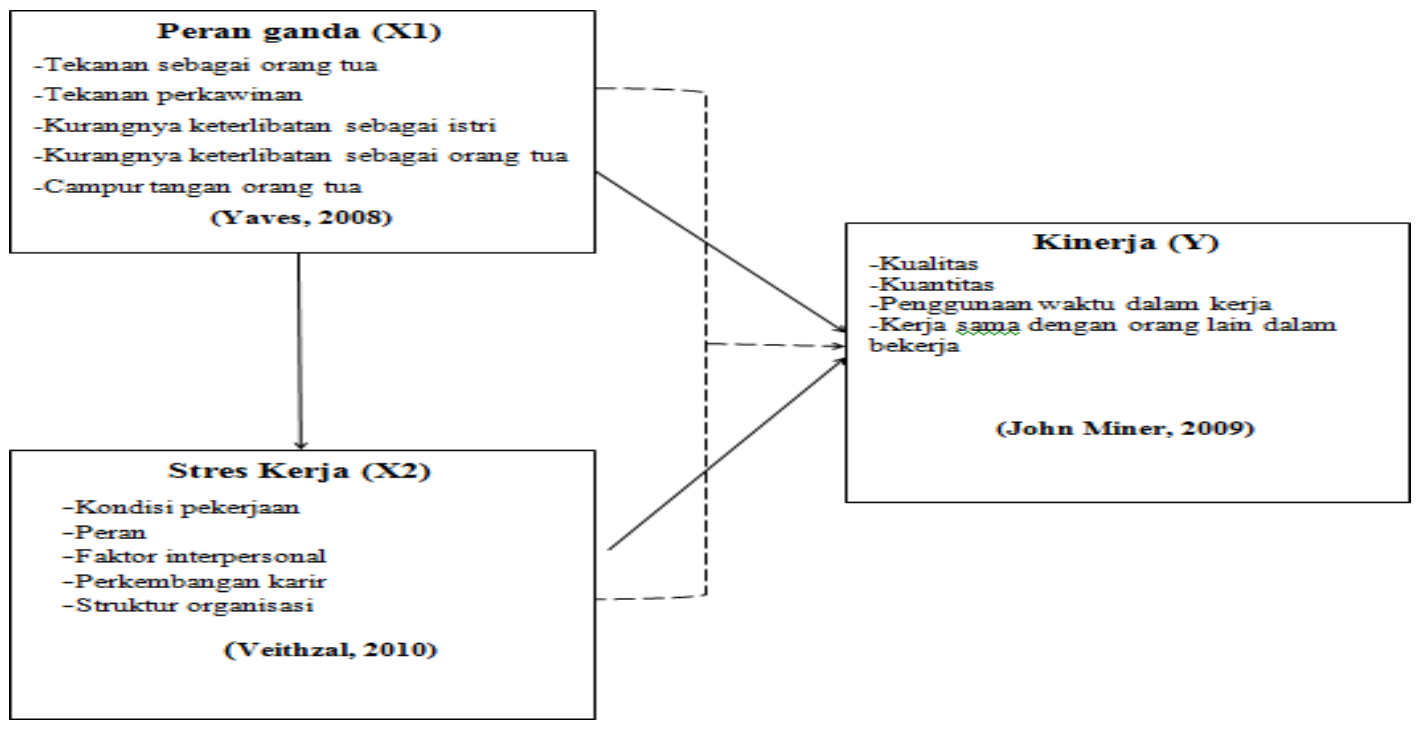

Gambar 1 Kerangka Pemikiran Penelitian 
Ketidakseimbangan antara pekerjaan domestik, yaitu memiliki tanggung jawab dalam hal mengurus keperluan rumah tangga, sehingga harus membagi waktu dan perhatiannya bagi keluarga dengan pekerjaan publik, yaitu sebagai seorang tenaga medis dapat mengakibatkan konflik peran ganda. Konflik peran ganda yang berkepanjangan akan memicuh timbulnya stress, yang pada akhirnya akan mengganggu kinerja baik sebagai ibu rumah tangga maupun kinerja sebagai tenaga medis wanita tentunya akan berdampak terhadap pelayanan yang diberikan atau menurunnya kualitas kerja.

\section{Hipotesis}

Hipotesis merupakan jawaban sementara yang dapat dirumuskan sebagai berikut:

H1 : Peran Ganda berpengaruh terhadap Kinerja Tenaga Medis Wanita di Puskesmas Baun Kabupaten Kupang.

H2 : Stres Kerja berpengaruh terhadap Kinerja Tenaga Medis Wanita di Puskesmas Baun Kabupaten Kupang.

H3 : Peran Ganda dan Stres Kerja berpengaruh terhadap Kinerja Tenaga Medis Puskesmas Baun Kabupaten Kupang.

H4: Peran Ganda berpengaruh terhadap Kinerja Melalui Stres Kerja Tenaga Medis Wanita di Puskesmas Baun Kabupaten Kupang.

\section{METODE PENELITIAN}

Pendekatan dalam penelitian ini adalah pendekatan kuantitatif, karena penelitian ini disajikan dengan angka-angka. Sedangkan dari segi eksplanasinya merupakan penelitian asosiatif, menurut Sugiyono (2003) penelitian asosiatif merupakan penelitian yang bertujuan untuk mengetahui pengaruh ataupun juga hubungan antara dua variabel atau lebih. Variabel-variabel yang digunakan dalam penelitian ini adalah :

1. Variabel terikat (dependent variable), yaitu kinerja tenaga medis (Z)

2. Variabel bebas (independent variable), yaitu peran ganda (X)

3. Variabel Intervening, yaitu stres kerja (Y)

Dalam penelitian ini yang menjadi populasi adalah seluruh tenaga medis wanita yang sudah menikah di Puskesmas Baun Kabupaten Kupang berjumlah 38 orang. Teknik pengambilan sampel dalam penelitian ini adalah total sampling yang mengambil keseluruhan populasi yang berjumlah 38 tenaga medis wanita yang sudah menikah. Teknik pengumpulan data yang digunakan yaitu observasi, kuesioner, dan dokumentasi.

Teknik analisis statistik deskriptif yang digunakan dalam penelitian ini, menurut Sugiyono (2014) merupakan salah satu metode dalam menganalisis data dengan menggambarkan data yang sudah dikumpulkan, tanpa membuat kesimpulan yang berlaku untuk umum (generalisasi). Data yang bersifat kuantitatif dianalisis dengan menggunakan analisis deskriptif kuantitatif dengan menggunakan rentang skor untuk mengetahui seberapa besar kualitas informasi secara objektif tanpa manipulasi subjektif untuk setiap variabel dalam model penelitian.

Rumus rentang skor :

$$
\begin{array}{lc} 
& \boldsymbol{R}=\frac{\text { skormaximum }- \text { skorminimum }}{\mathrm{JK}} \\
\text { Keterangan: } & \mathrm{R}=\text { Rentang } \\
& \mathrm{JK}=\text { Jarak Kelas }
\end{array}
$$

Kemudian dilakukan Analisis Regresi Linear Berganda. Analisis ini untuk mengetahui arah hubungan antara variabel indenpen (peran ganda) dengan variabel dependen (kinerja) dan variabel intervening (stres kerja) dengan variabel dependen (kinerja), variabel apakah masingmasing variabel independen dan variabel intervening berhubungan positif atau negatif dan untuk memprediksi kenaikan atau penurunan. Persamaan regresi linear berganda adalah sebagai berikut : 
Women Medical

Personnel

Performance

$\underline{182}$

$$
\begin{aligned}
& Y=\alpha+\beta_{1} X_{1}+\beta_{2} X_{2}+\varepsilon \\
& \text { Keterangan : } \\
& \mathrm{Y}=\text { Kinerja }(\mathrm{Z}) \\
& \mathrm{X} 1, \mathrm{X} 2 \text { = Peran Ganda, Stres Kerja }(\mathrm{X}, \mathrm{Y}) \\
& \beta_{1}, \beta_{2}, \quad=\text { Koefisien regresi } X_{1}, X_{2} \text {, (Koefisien } X, Y \text { ) } \\
& \alpha \quad=\text { Konstanta (Nilai } Y \text {, apabila X1, X2=0) } \\
& \mathrm{e}=\text { Errorterm }
\end{aligned}
$$

Untuk melakukan uji hipotesis digunakan uji t untuk menguji sendiri-sendiri secara signifikan hubungan antara variabel independen (X) dan variabel dependen (Y) dengan kriteria pengujian sebagai berikut :

1) Jika t hitung $>$ tabel, maka variabel indenpenden mempunyai keeratan hubungan yang signifikan terhadap variabel dependen

2) Jika t hitung < tabel, maka variabel independen tidak mempunyai keeratan hubungan yang signifikan dengan variabel dependen.

Uji $\mathrm{F}$ digunakan untuk melihat daya ramai dan sampel dalam variabel independen terhadap variabel dependen.

1) Jika $\mathrm{F}$ hitung < dari $\mathrm{F}$ tabel, maka variabel independen tidak bepengaruh signifikan terhadap variabel dependen.

2) Jika $\mathrm{F}$ hitung $>\mathrm{F}$ tabel, maka variabel independen mempunyai hubungan yang signifikan terhadap variabel dependen.

Uji Koefisien determinasi $\left(\mathrm{R}^{2}\right)$ pada intinya mengukur seberapa jauh kemampuan model dalam menerangkan variasi variabel dependen. Koefisien determinasi merupakan ukuran untuk mengetahui kesesuain atau ketetapan antara nilai dugaan atau regresi dengan data sampel. (Ghozali, 2012 ). Nilai koefisien determinasi adalah antara nol dan satu. Nilai $\mathrm{R}^{2}$ yang kecil berarti kemampuan variabel-variabel independen dalam menjelaskan variasi variabel dependen terbatas. Nilai yang mendekati satu berarti variabel-variabel independen memberikan hampir semua informasi yang dibutuhkan untuk memprediksi variasi variabel dependent.

Pengujian hipotesis mediasi dapat dilakukan dengan prosedur yang dikembangkan oleh Sobel (1982) dan dikenal dengan Uji Sobel (Sobel Test). Uji Sobel digunakan dengan menguji kekuatan pengaruh tidak langsung variabel peran ganda $(X)$ terhadap variabel kinerja $(Z)$ melalui variabel stres kerja (Y), dihitung denngan cara mengalihkan koefesien jalur variabel peran ganda $(X)$ terhadap kinerja $(Z)$ (a) dengan koefesien jalur $Y$ terhadap $Z_{(b)}$ atau ab. Standar error koefesien $a$ dan $b$ ditulis dengan $S_{a}$ dan $S_{b}$ besarnya standar eror tidak langsung (indirect effect) $\mathrm{S}_{\mathrm{ab}}$. Standar error tidak langsung (indirect effect) $\mathrm{S}_{\mathrm{ab}}$ dihitung dengan rumus berikut ini :

$$
s_{a b}=\sqrt{b^{2} s a^{2}+a^{2} s b^{2}+s a^{2} s b^{2}}
$$

Keterangan :

a $\quad=$ Koefesiensi regresi variabel peran ganda terhadap variabel stres kerja

$\mathrm{b} \quad=$ koefesiensi regresi variabel stres kerja terhadap variabel kinerja

$\mathrm{S}_{\mathrm{a}} \quad=$ Standar error dari variabel peran ganda terhadap variabel stres kerja

$\mathrm{S}_{\mathrm{b}} \quad=$ Standar error dari variabel stres kerja terhadap variabel kinerja

\section{HASIL DAN PEMBAHASAN}

\section{Hasil Analisis Regresi Linear Berganda}

Regresi berganda digunakan untuk mengetahui bagaimana pangaruh variabel bebas (peran ganda) terhadap variabel terikat (kinerja) dan pengaruh variabel intervening (stress kerja) terhadap variabel terikat (kinerja). Berikut ini adalah tabel hasil analisis regresi linear berganda dengan data $(n=38)$ menggunakan aplikasi SPSS V.17. 
Tabel 1 Hasil Analisis Regresi Berganda

\begin{tabular}{|c|c|c|c|c|c|c|}
\hline \multirow{2}{*}{\multicolumn{2}{|c|}{ Model }} & \multicolumn{2}{|c|}{ Unstandardized Coefficients } & \multirow{2}{*}{$\frac{\text { Standardized Coeff. }}{\text { Beta }}$} & \multirow[b]{2}{*}{$\mathrm{t}$} & \multirow[b]{2}{*}{ Sig. } \\
\hline & & $\mathrm{B}$ & Std. Error & & & \\
\hline 1 & (Constant) & 27.783 & 3.184 & & 8.726 & .000 \\
\hline & PERANGANDA & .518 & .158 & .732 & 3.277 & .002 \\
\hline & STRESKERJA & -.101 & .135 & -.166 & -.742 & .463 \\
\hline
\end{tabular}

Women Medical

Personnel

Performance

a. Dependent Variable: Kinerja Karyawan

Sumber: Hasil Pengolahan Data Primer, 2020

Melalui tabel 1 di atas, maka dapat diperoleh persamaan regresi linear berganda, yaitu : $Y=27,783+0,518 X-0,101 Y$. Dari persamaan yang diketahui maka dapat dijelaskan sebagai berikut :

1. Hasil output pengujian regresi linear berganda menunjukan nilai positif pada konstanta sebesar 27,783. Dapat diartikan bahwa, jika variabel Peran Ganda (X) dan Stres Kerja (Y) bernilai nol (0) maka nilai pad variabel Kinerja sebesar 27,783.

2. Variabel Peran Ganda (X) mempunyai nilai koefesien (B) sebesar 0,518 yang berarti apabila terjadi kenaikan 1 poin, maka Kinerja (Z) meningkat sebesar 0,518.

3. Variabel Stres Kerja (Y) mempunyai nilai koefesien (B) sebesar -0,101 yang berarti jika terjaadi kenaikan 1 poin, maka Kinerja (Y) meningkat sebesar -0,101.

\section{Hasil Pengujian Hipotesis Secara Parsial (Uji t)}

Uji t digunakan untuk menentukan apakah variabel Peran ganda dan Stres kerja secara individu atau parsial berpengaruh terhadap variabel Kinerja. Jumlah responden pada penelitian ini adalah 38 dan jumlah variabel sebanyak 2 variabel, pada tingkat signifikansi $5 \%$ maka df $=38-2-1=34$ dengan tingkat signifikansi 2 arah yaitu 2,032 sehingga nilai ttabel pada penelitian ini adalah 2,032. Berdasarkan hasil analisis data diketahui bahwa variabel Peran Ganda (X) memiliki nilai signifikan. $\mathrm{t}<$ alpha yaitu $0,002<0,05$ dan thitung $>$ ttabel yaitu sebesar 3,277 > 2,032. Maka nilai hipotesis nol $\left(\mathrm{Ho}_{\mathrm{O}}\right)$ di tolak dan hipotesis alternatif (Ha) diterima. Dengan demikian dapat disimpulkan bahwa terdapat pengaruh secara positif dan signifikan antara variabel Peran Ganda (X) terhadap Kinerja (Z) tenaga medis wanita di Puskesmas Baun Kabupaten Kupang. Selanjutnya diketahui bahwa variabel Stres Kerja (Y) memiliki nilai signifikan. $\mathrm{t}<$ alpha yaitu $0,463>0,05$ dan thitung $<$ ttabel yaitu sebesar $0,101<2,032$. Maka nilai hipotesis nol $\left(\mathrm{H}_{\mathrm{O}}\right)$ diterima dan hipotesis alternatif $(\mathrm{Ha})$ ditolak. Dengan demikian dapat disimpulkan bahwa terdapat pengaruh negatif dan tidak signifikan antara variabel Stres Kerja (Y) terhadap Kinerja (Z) tenaga medis wanita di Puskesmas Baun Kabupaten Kupang.

\section{Hasil Pengujian Secara Simultan (Uji F)}

Tabel 2 Hasil Uji F (Simultan)

\begin{tabular}{|c|c|c|c|c|c|c|}
\hline \multicolumn{2}{|c|}{ Model } & Sum of Squares & Df & Mean Square & F & Sig. \\
\hline 1 & Regression & 463.733 & 2 & 231.866 & & \\
\cline { 1 - 5 } & Residual & 792.267 & 35 & 22.636 & \multirow{2}{*}{10.243} & $.000^{\mathrm{a}}$ \\
\hline & Total & 1256.000 & 37 & & & \\
\hline
\end{tabular}

a. Predictors: (Constant), STRESKERJA, PERANGANDA

b. Dependent Variable: KINERJAKARYAWAN

Sumber: Hasil Pengolahan Data Primer, 2020

Berdasarkan hasil uji F diketahui nilai Fhitung sebesar 10,243. Nilai Ftabel pada taraf signifikansi $5 \%$, df1 $=2$, df2 $=35$ adalah sebesar 3,250. Nilai Fhitung $>$ Ftabel yaitu 10,243 $>$ 3,250 dan mempunyai nilai signifikansi sebesar 0,000 < 0,05 maka $\mathrm{Ho}$ ditolak dan $\mathrm{Ha}$ diterima, Artinya Peran Ganda dan Stres Kerja secara simultan berpengaruh signifikan terhadap Kinerja Tenaga Medis Wanita di Puskemas Baun Kabupaten Kupang

\section{Koefesien Determinasi}


Women Medical

Personnel

Performance
Koefisien determinasi $\left(\mathrm{R}^{2}\right)$ digunakan untuk mengetahui seberapa besar pengaruh yang diberikan variabel Peran Ganda (X), Stres Kerja (Y) Kinerja (Z). Berikut adalah hasil uji koefisien determinasi $\left(\mathrm{R}^{2}\right)$.

Tabel 3. Hasil Uji Koefisien Determinasi $\left(\mathbf{R}^{2}\right)$

\begin{tabular}{|c|c|c|c|c|}
\hline Model & $\mathrm{R}$ & $\mathrm{R}$ Square & Adjusted R Square & Std. Error of the Estimate \\
\hline 1 & $.608^{\mathrm{a}}$ & .369 & .333 & 4.758 \\
\hline
\end{tabular}

b. Predictors: (Constant), STRESKERJA, PERANGANDA

Sumber: Hasil Pengolahan Data Primer, 2020

Berdasarkan tabel di atas diketahui bahwa nilai koefisien determinasi atau $\mathrm{R}$ Square adalah sebesar 0,369 atau 36,9\%. Nilai ini menunjukkan bahwa pengaruh peran ganda (X), dan stres kerja (Y) terhadap variabel kinerja (Z) adalah sebesar 36,9\%, sedangkan sisanya $0,631(1-0,369=0,631)$ atau $63,1 \%$ dipengaruhi oleh variabel lain di luar variabel yang diteliti.

\section{Uji Sobel}

Pengujian hipotesis mediasi dapat dilakukan dengan prosedur yang dikembangkan oleh Sobel (1982) dan dikenal dengan Uji Sobel (Sobel Test). Uji Sobel digunakan dengan menguji kekuatan pengaruh tidak langsung variabel peran ganda $(X)$ terhadap variabel kinerja $(Z)$ melalui variabel stres kerja (Y), dihitung dengan cara mengalihkan koefesien jalur variabel peran ganda $(X)$ terhadap kinerja $(Z)$ (a) dengan koefesien jalur $Y$ terhadap $Z(b)$ atau ab. Standar error koefesien a dan $\mathrm{b}$ ditulis dengan $\mathrm{Sa}$ dan $\mathrm{Sb}$ besarnya standar eror tidak langsung (indirect effect) $\mathrm{S}_{\mathrm{ab}}$-.Standar error tidak langsung (indirect effect) $\mathrm{S}_{\mathrm{ab}}$ dihitung dengan rumus berikut ini :

$$
\begin{aligned}
\boldsymbol{s}_{\boldsymbol{a b}} & =\sqrt{\boldsymbol{b}^{2} \boldsymbol{s} \boldsymbol{a}^{2}+\boldsymbol{a}^{2} \boldsymbol{s} \boldsymbol{b}^{2}+\boldsymbol{s} \boldsymbol{a}^{2} \boldsymbol{s} \boldsymbol{b}^{2}} \\
s_{a b} & =\sqrt{0,101^{2} 0,117^{2}+0,932^{2} 0,135^{2}+0,177^{2} 0,135^{2}} \\
s_{a b} & =\sqrt{0,003+0,0158+0,0005+0,000} \\
s_{a b} & =\sqrt{0,134} \\
\mathrm{t} & =\frac{a b}{S a b} \quad \mathrm{t}=\frac{0,932 \times 0,101}{0,134} \quad \mathrm{t}=0,702
\end{aligned}
$$

Dari hasil sobel test diatas diperoleh nilai thitung sebesar 0,702. Karena nilai thitung lebih kecil dari nilai ttabel $(0,702<2,032)$ dengan tingkat signifikan 5\% $(0,05)$, maka membuktikan bahwa Stres Kerja tidak mampu memediasi hubungan pengaruh peran ganda terhadap kinerja tenaga medis wanita di Puskesmas Baun Kabupaten Kupang melalui stres kerja sebagai variabel intervening.

Di dalam diagram jalur yang perlu diperhatikan adalah anak panah berkepala satu merupakan hubungan regresi. Hubungan langsung terjadi jika satu variabel memengaruhi variabel lain tanpa ada variabel ketiga yang memediasi (intervening) hubungan kedua variabel tadi. Pada setiap variabel independen akan ada anak panah yang menunjukan ke variabel ini (mediasi) dan ini berfungsi untuk menjelaskan jumlah varian yang tidak dapat dijelaskan oleh variabel lain (Ghozali, 2005). Jadi tenaga medis tidak dapat menjalankan tugasnya jika adanya Peran Ganda dan Stres Kerja. Peran ganda dapat memengaruhi kinerja secara langsung tanpa melalui Stres kerja sebagai variable intervening. Stres Kerja memengaruhi peran ganda dan Kinerja secara langsung. Namun, stres kerja tidak dapat secara langsung memengaruhi kinerja tenaga medis wanita. Dalam hasil penelitian ini membuktikan bahwa Stres Kerja terbukti secara penuh tidak dapat memengaruhi Peran Ganda terhadap Kinerja Sebagai Variabel Intervening.

Pengaruh Peran Ganda Terhadap Kinerja

Berdasarkan hasil uji t menunjukan nilai thitung variabel Peran Ganda (X) sebesar 3,277 pada taraf signifikan $5 \%$. Nilai thitung $>$ ttabel yaitu $3,277>2,032$. Hasil ini menunjukan 
bahwa Peran Ganda berpengaruh terhadap Kinerja. Cinamon dan Rich (2002) menunjukkan wanita atau ibu yang bekerja ternyata lebih sering mengalami work family conflict dan lebih menekankan pentingnya family work conflict, ketika keluarga sebagai domain yang paling penting bagi kebanyakan wanita mempengaruhi pekerjaan mereka dan dapat menjadi gangguan bagi mereka.

Dalam hal ini tenaga medis wanita terkadang mengalami permasalahan dalam keluarga, tidak mendapat dukungan dan adanya keluhan akibat pekerjaan yang mereka lakukan serta tuntutan urusan keluarga yang membatasi jam kerja di Puskesmas mengharuskan mereka untuk bisa menjalankan tugas dan tanggung jawabnya dalam mengatur waktu, tenaga dan fikirannya agar tetap mampu memberikan kualitas dalam mengurus rumah tangga dan juga pekerjaan. Kondisi tersebut memicuh terjadinya konflik peran ganda yang jika tidak dapat ditangani secara tepat dan bijaksana, maka dapat berakibat langsung pada tenaga medis wanita sehingga mengalami tekanan yang memengaruhi hasil kerja.

\section{Pengaruh Stres Kerja Terhadap Kinerja}

Berdasarkan hasil uji t menunjukan nilai thitung variabel kinerja $(Z)$ pada taraf signifikan 5\% adalah sebesar $-7,42$ Nilai thitung $<$ ttabel yaitu $-7,42<2,032$. Hasil ini menunjukan bahwa Stres Kerja tidak berpengaruh terhadap Kinerja. Robins (2006) menyatakan tingkat stres yang mampu dikendalikan membuat tenaga medis melakukan pekerjaannya dengan lebih baik, karena membuat mereka mampu meningkatkan intensitas kerja, kewaspadaan, dan kemampuan berkreasi, tetapi tingkat stres kerja yang berlebihan membuat kinerja mereka akan mengalami penurunan.

Stres kerja bukanlah suatu hal yang selalu berakibat buruk bagi para tenaga medis wanita \& kinerjanya, melainkan stres kerja juga dapat memberikan motivasi bagi mereka untuk memupuk rasa semangat dalam menjalankan setiap pekerjaannya sehingga mencapai suatu prestasi kerja yang baik seperti penanganan pasien yang dulunya lambat menjadi lebih cepat, menciptakan keunggulan kompetitif dengan pelayanan yang baik serta adanya batasan waktu sehingga dapat menjadi lebih efisien dan efektif. Pengelola stres yang dilakukan secara berkesinambungan maka tidak akan menghambat kinerja setiap tenaga medis wanita.

\section{Pengaruh Peran Ganda dan Stres Kerja Terhadap Kinerja}

Berdasarkan hasil uji F diketahui nilai Fhitung $>$ Ftabel yaitu 10,243 > 3,250 dan mempuyai nilai signifikansi sebesar $0,000<0,05$. Maka Peran Ganda dan Stres Kerja secara simultan berpengaruh signifikan terhadap Kinerja Tenaga Medis Wanita di Puskemas Baun Kabupaten Kupang. Hutasuhut (2012) menyatakan bahwa kemampuan individu dalam mengambil sikap keputusan dapat mengakibatkan stress kerja. Faktor yang domain stress kerja tenaga medis disebabkan kondisi yang di hadapi setiap hari, baik dalam pekerjaan ataupun dalam kehidupan sehari-hari. Hal ini sejalan dengan teori Wirawan (2009) yang menyatakan bahwa faktor yang memengaruhi kinerja adalah stress kerja.

Ketidakseimbangan antara pekerjaan domestik, yaitu dalam mengurus rumah tangga dengan pekerjaan publik, yaitu sebagai seorang tenaga medis mengakibatkan konflik peran ganda dimana kurang atau bahkan tidak adanya waktu bersama keluarga membuat konsentrasi dalam bekerja terganggu serta tuntutan pekerjaan yang terus menerus dapat menimbulkan stres kerja yang akan mengangganggu kinerja baik sebagai ibu rumah tangga maupun sebagai tenaga medis wanita sehingga berdampak terhadap palayan yang diberikan atau menurunnya kualitas kerja.

Pengaruh Peran Ganda Terhadap Kinerja Melalui Stres Kerja

Dari hasil sobel test diperoleh nilai thitung sebesar 0,702. Karena nilai thitung lebih kecil dari nilai ttabel $(0,702<2,032)$ dengan tingkat signifikan $5 \%(0,05)$, maka membuktikan bahwa Stres Kerja tidak mampu memediasi hubungan pengaruh Peran Ganda terhadap
Women Medical

Personnel

Performance 
Women Medical

Personnel

Performance

186
Kinerja tenaga medis wanita di Puskesmas Baun Kabupaten Kupang. Triarty (2003), menyatakan bahwa konflik pekerjaan keluarga pada karyawan yang sudah menikah dan mempunyai anak dapat di definisikan sebagai bentuk konflik peran dimana tuntutan dari peran pekerjaan kurang dapat dipenuhi karena pada saat yang sama seseorang berusaha memenuhi tuntutan peran yang lain. Konflik peran ganda yang tidak ditangani secara tepat dan bijaksana, dapat pula berakibat langsung pada diri tenaga medis wanita, karena mereka dalam keadaan suasana serba salah sehingga mengalami tekanan jiwa (stress kerja).

Jadi tenaga medis tidak dapat menjalankan tugasnya jika adanya Peran Ganda dan Stres Kerja. Peran ganda dapat memengaruhi kinerja secara langsung tanpa melalui Stres kerja sebagai variable intervening. Stres Kerja memengaruhi peran ganda dan Kinerja secara langsung. Namun, stres kerja tidak dapat secara langsung memengaruhi kinerja tenaga medis wanita. Dalam hasil penelitian ini membuktikan bahwa Stres Kerja terbukti secara penuh tidak dapat memengaruhi Peran Ganda terhadap Kinerja Sebagai Variabel Intervening, melainkan variabel Stres kerja sebagai Variabel independent.

\section{PENUTUP}

Berdasarkan penelitian yang dilakukan di Puskesmas Buan Kabupaten Kupang mengenai Pengaruh Peran Ganda Terhadap Kinerja Tenaga Medis melalui Stres Kerja dapat diambil kesimpulan bahwa :

1) Peran ganda berpengaruh terhadap kinerja tenaga medis wanita di Puskemas Baun Kabupaten Kupang. Tuntutan dua peran sekaligus secara bersamaan mengakibatkan tekanan yang memengaruhi hasil kerja yang dicapai oleh setiap tenaga medis wanita.

2) Stres kerja berpengaruh negatif dan tidak signifikan terhadap kinerja tenaga medis wanita di Puskesmas Baun Kabupaten Kupang. Stres kerja sama sekali tidak memengaruhi kinerja tenaga medis wanita, dikarenakan pengelolahan stres kerja yang baik dengan memberikan motivasi dan meningkatkan efesiensi dan efektifitas kerja tenaga medis wanita untuk melakukan tugas lebih baik.

3) Hasil pengujian hipotesis secara simultan membuktikan bahwa Peran Ganda dan Stres Kerja mempunyai hubungan terhadap kinerja Tenaga Medis Wanita di Puskesmas Baun Kabupaten Kupang.

4) Berdasarkan uji sobel, Stres Kerja tidak mampu memediasi hubungan pengaruh Peran Ganda terhadap Kinerja Tenaga Medis Wanita di Puskesmas Baun Kabupaten Kupang.

\section{DAFTAR PUSTAKA}

[1] AA. Anwar Prabu Mangkunegara, 2013, Manajemen Sumber Daya Manusia Perusahaan, Remaja Rosdakarya, Bandung.

[2] Almasitoh, U. H. 2011. Stres Kerja Ditinjau Dari Konflik Peran Ganda Dan Dukungan Sosial Pada Perawat. Psikoislamika - Jurnal Psikologi Islam. No. 8 Vol.1, 63-82. Klaten : Universitas Widya Dharma.

[3] Anoraga , 2011, Psikologi Manajemen, Rineka Cipta, Bandung.

[4] Arikunto, Suharsimi. 2011. Prosedur Penelitian: Suatu Pendekatan Praktik. Edisi Revisi VII. Jakarta: PT. Rineka Cipta.

[5] Astrini, D., Juanda, B., \& Achsani, N. A. (2016). Impact Of Redenomination On Price, Volume, And Value Of Transaction: An Experimental Economic Approach. Bulletin of Monetary Economics and Banking, 19(2), 1-32.

[6] Cinnamon, R. G. and Y. Rich (2002). Gender differences in the importance of work and family roles: Implication for work-family conflict. Sex Roles: A Journal of Research 47: 531-541. Cohen, S. and S. L. Sy

[7] Gibson, James. L,.et all.2012. Organisasi, Perilaku, Struktur, Proses, Edisi Ke-5. Jakarta. Erlangga. 
[8] Gorda, I Gusti Ngurah. 2004. Manajemen Sumber Daya Manusia. Edisi Revisi. Denpasar: Astabrata Bali bekerjasama dengan STIE Satya Dharma Singaraja.

[9] Gozila, H. Imam. (2012). Aplikasi Analisis Multivariate dengan program IBM SPSS. Edisi enam. Semarang: Universitas Diponegoro.

[10] Handoko.2008. Manajemen Personalia dan Sumber Daya Manusia. Yogyakarta: BPFE. Hutasuhut, Amrizal. 2014. Gambaran Stressor dan Stres Kerja Perawat Kamar Bedah di Rumah Sakit Umum Daerah dr. Pirngadi Kota Medan.

[11] Luthans, F., (2001) Organizational Behavior, Seventh Edition, Singapore: Mc Graw Hill.

[12] Moeheriono. 2012. "Pengukuran Kinerja Berbasis Kompetensi". Jakarta: Raja Grafindo Persada.

[13] Mulyana, M. (2012). Consumer Behaviour: Sukses Dengan Memahami Konsumen.

Women Medical

Personnel

Performance

[14] Mulyana, M., Hakim, D. B., \& Hartoyo, S. (2020). Entrepreneurial Activities And Performance Of Rice Farming In Bojongpicung Sub-District, Cianjur Regency. European Journal of Molecular \& Clinical Medicine, 7(3), 4528-4535.

[15] Mulyana, M., Rainanto, B. H., Astrini, D., \& Puspitasari, R. (2020). Persepsi Mahasiswa Atas Penggunaan Aplikasi Perkuliahan Daring Saat Wabah Covid-19. JASPT (Jurnal Analisis Sistem Pendidikan Tinggi Indonesia), 4(1), 47-56.

[16] Murdihardjo, L., Nurjanah, Y., \& Rendy, R. (2020, May). Implementing INTACS Dynamics Enterprise Resources Planning System for Financial Statements. In 2nd International Seminar on Business, Economics, Social Science and Technology (ISBEST 2019) (pp. 228-233). Atlantis Press.

[17] Nurendah, Y. (2015). Strategy to Improvement Sustainability of Distinctively Local Snacks Based on Evaluation and Profile Mapping of SMEs Distinctively Local Snacks. International Journal on Advanced Science, Engineering and Information Technology, 5(5), 334-338.

[18] Nurjanah, Y. (2020). Peningkatan Kapabilitas Pelaku UMKM Dalam Penyusunan Laporan Keuangan. Jurnal Abdimas, 4(2), 171-180.

[19] Nyoman Triarti, 2003. Pengaruh Adaptasi Kebijakan Mengenai Work Family Issue Terhadap Absen dan Turnover. Jurnal Manajemen \& Kewirausahaan Vol. 5, No. 1, Maret 2003: 85-96.

[20] Pamungkas, B., \& Kusumahdinata, A. (2011). Evaluasi Aplikasi Sistem Informasi Manajemen Akuntansi Barang Milik Negara (SIMAK BMN) Kaitannya Dalam Pencatatan Nilai Aset Tetap Pemerintah Studi Kasus pada Pusat Penelitian dan Pengembangan Tanaman Pangan Bogor. Jurnal Ilmiah Akuntansi dan Manajemen Ranggagading, 11(2), 082-090.

[21] Pamungkas, B., \& Iriyadi, I. (2012). Analisa Atas Pelaksanaan Audit Mutu Internal Untuk Mengevaluasi Efektifitas Penerapan Sistem Manajemen Mutu ISO 9001: 2000 Studi kasus pada PT. Murni Cahaya Pratama. Jurnal Ilmiah Kesatuan (JIK), 9(2).

[22] Rahmadita Irma. 2013. "Hubungan Antara Konflik Peran Ganda Dan Dukungan Sosial Pasangan Dengan Motivasi Kerja Pada Karyawati Di Rumah Sakit Abdul Rivai Berau". eJurnal Psikologi. Vol. 1, No. 1, hml.58-68.

[23] Rina Indra Iswari, Ari Pradhanawati, 2018. "Pengaruh Peran Ganda, Stres Kerja Dan Motivasi Kerja Terhadap Kinerja Karyawan Perempuan". Skripsi

[24] Robbins dan Judge, 2011, Perilaku Organisasi, Edisi 12, Salemba Empat

[25] Sugiyono, 2014, Metode Penelitian Kuantitatif, Kualitatif dan R\&D, Bandung : Alfabeta.

[26] Suryadi, Denrich. (2004). Gambaran Konflik Emosional dalam Menentukan Prioritas Peran Ganda, Jurnal Ilmiah Psikologi Arkhe 1. 
Women Medical

Personnel

Performance
[27] Susilantini, Endah. 2006. Peran Ganda Wanita Indonesia. Jurnal Jantra (Sejarah dan Budaya). 2 (1): 99- 105

[28] Veithzal Rivai dan Ella Jauvani Sagala, 2011.Manajemen Sumber Daya Manusia untuk Peursahaan dari Teori ke Praktik. PT Raja Grafindo, Jakarta

[29] Wibowo, 2014, Pengaruh Budaya Organisasi, Kepuasan Kerja dan Gaya Kepemipinan terhadap Kinerja Karyawan.

[30] Widodo, Untung. 2006. Analisis Pengaruh Gaya Kepemimpinan dan Kepuasan Kerja Terhadap Kinerja Bawahan (Studi Empiris pada Perguruan Tinggi Swasta di Kota Semarang). Jurnal Fokus Ekonomi. Vol 1, No 2: 92-108. 